\title{
Aspects of relevance in the Romanian political discourse
}

\author{
Ana Ene* \\ Faculty of Letters, "Transilvania" University of Brașov, Bd. Eroilor 29, 500036 Brașov, Romania
}

\section{Article info}

History:

Received August 12, 2018

Accepted August 30, 2018

Published May 7, 2019

Key words:

rhetoric

stylistics

sociolinguistics

\begin{abstract}
This paper investigates political discourse from the perspective of relevance theory in relation to the function of reasonable persuasion oriented towards voters. The research' objectives are to identify and to describe: 1) the mechanisms of persuasion used in election campaign speeches; 2) the meta-strategy of miming dialogue; 3) the manner in which political discourse infringes upon the principles of relevance. The accomplishment of the objectives requires a twofold methodology: rhetorical and linguistic by means of instruments of lexicalsemantic, pragma-stylistic and logical-argumentative analysis. The research is focused on political election campaigns speeches: slogans and speeches of the Romanian recent election campaigns.

The most frequently encountered discourse strategies are: i) the use of various types of fallacious reasoning and ii) vague language.
\end{abstract}

\section{Introduction}

The subject of this paper is Romanian political discourse from the perspective of relevance theory (Sperber \& Wilson, 1995). An outline of this area of investigation involves certain approaches to the rhetoric of propaganda discourse in general and to political discourse in particular. The research is focused on the political speeches delivered in election campaigns. The corpus mainly comprises the slogans and speeches of the political actors involved in the election campaign for the parliamentary elections held on 11 December 2016 and for the local elections held on 5 June 2016. Both the outdoor and the indoor forms of political campaign advertising are considered, as well as several fragments of speeches delivered at various assemblies or in television interviews.

The objectives of the research are the following: 1) to identify and to describe the mechanisms of various persuasion strategies used by politicians in campaign speeches; 2) to identify and describe the processes involved in the meta-strategy of miming dialogue in this type of speech; 3) to identify and describe the manner in which the above-mentioned strategies infringe upon the principles of relevance.

The rhetorical dimension of the methodology required by the above-mentioned objectives involves some elements of logical-argumentative analysis. Also, given the necessity to take into consideration the context as well as the parameters of the situation of enunciation which are specific to the analysed discourses, it will be compulsory to resort to the instruments furnished by the lexical-semantic and pragmastylistic analysis. This two-fold methodology is based on "a correlation between pragmatic and rhetoric resources of speech-building". This is because the series of structural categories belonging to pragmatics, and respectively rhetoric "distribute in parallel the same linguistic resources" (Ionescu-Ruxăndoiu, 2007, p. 313).

The main assumption is that the cognitive and communicative principles of relevance are frequently infringed upon in political discourse in general, and in campaign discourse in particular. Hence, the proportion between relevance and comprehension is taken into consideration only in consonance with its formal parameters but hindered in substance. Specifically, the communicative intention is not meant to furnish correct information to voters in order to ensure a background of reasonable reflexion, but to

*Email address: enea@unitbv.ro. 
persuade them by capitalizing on the emotional component by presenting subjective facts in the guise of objective data. In the distorted presentation of facts, the most frequently encountered strategies are: i) the massive use of ad verecundiam ${ }^{1}$, ad hominem ${ }^{2}$ and ad ignorantiam ${ }^{3}$ types of argument instead of ad judicium $^{4}$ arguments, ii) fallacious reasoning and iii) vague language or, on the contrary, the seemingly plausible language grounded on data, sources, figures, etc. Moreover, a meta-strategy is miming dialogue with voters by means of various rhetorical-stylistic techniques. The receptor is drawn into a sort of communicational complicity which is often founded on false assumptions, with a definite intention to convert the assent of the receptor-who is already a partaker of the statements, ideas and interpretations of the respective discursive political figure-into a favourable vote.

\section{Relevance and political discourse}

In a preliminary phase of the corpus elements analysis, a few questions have emerged. The answers to these questions are intended to clarify the general context in which the discourses or discourse fragments analysed are performed. On the other hand, it is important to understand the manner in which the process of influencing the public through political discourse develops.

\subsection{Some questions and some answers}

So, who says what, where, when and how? What are the situational contexts? An adequate pragmatic reception of the elements of the analysed corpus, in order to reduce the communicative discrepancy or, in other words, in such a way as to facilitate the communicative action game (Plett, 1983), requires not only the indication of the parameters of the situation of enunciation (who, what, where, when, how) but also a succinct layout of the situational context (more or less recent internal political events, facts and events evoked in the speeches subjected to analysis).

How, to what extent and why is the receptor's interpretation of political speech influenced? Indeed, "[...] a context is not given once and for all, but is constructed, enunciation after enunciation, by the interlocutor, on the basis of information coming from different sources and on the basis of the principle of pertinence" (Sperber \& Wilson, 1995). But everything starts from intent: if the intent is to manipulate, then the concept of discursive pertinence is corrupted from the start. Unfortunately, very often relevance becomes irrelevant in political discourse.

Relevance (or pertinence), central concept of relevance theory (Sperber \& Wilson, 1995), represents the ensemble of effects obtained at the end of the interpretation process and of the processing efforts in the course of this. The essence of principle of pertinence / relevance is that any enunciation should provide an assurance of pertinence (Sperber \& Wilson, 1995, p. 83). Pursuant to that principle: (i) an enunciation will be all the more pertinent as it produces more contextual effects; (ii) an enunciation is all the more relevant as fewer processing efforts require it. The processing efforts, obviously, belong to the receptor, but the politicians (the authors of speeches) want that receptor to be guided depending on the effects expected by them.

On the other hand, communicative intention consists in „making it mutually manifest to the audience and communicator when the communicator has this informative intention" (Sperber \& Wilson, 1995, p. 61). But they talk here, of course, about genuine communicative intent. Here we must put another question: does relevance of the political enunciations serve an authentic communicative intention (in

\footnotetext{
${ }^{1}$ Ad verecundiam is a way of argumentation which makes use of the opponent's respect for the opinion of a person or people who have gained their reputation in the eyes of the common opinion (through culture, distinction, power and intellectual faculties); the rejection leads to the categorization of the opponent as an arrogant and disdainful person.

${ }^{2}$ Ad hominem argumentum presupposes that the interlocutor is cornered with consequences drawn from his own principles or confessions.

${ }^{3}$ Ad ignorantiam argumentum implies that the interlocutor either admits the speaker's opinion or is constrained to provide a better solution.

${ }^{4}$ Ad judicium argumentum is the use of evidence drawn from some sources of knowledge or of probability.
} 
Sperber \& Wilson's terms) or, conversely, a persuasive process which has completely different intentions? Of course, it's a rhetoric question...

Therefore, our task will be to denounce those strategies by which relevance is corrupted by a manipulative communicative intent in political discourse. And these strategies are even more prominent in the political speech of the electoral campaigns.

\subsection{About the extent-conditions of relevance}

According to Sperber \& Wilson (1995, p. 125), in order to obtain a statement with a high degree of relevance, information processing efforts can be reduced through an increased production of contextual effects. Thus, the authors consider that the definition of relevance can be improved by adopting two extent conditions:

Extent condition 1: an assumption is relevant in a context to the extent that its contextual effects in this context are large.

Extent condition 2: an assumption is relevant in a context to the extent that the effort required to process it in this context is small.

This definition implies the necessary and sufficient condition of definition $(7)^{5}$, which therefore need not be stated independently.

The contextual effects are the product of interpreting the enunciations in relation to a peculiar context and can be obtained by three ways: (1) addition of information, (2) suppression of information, (3) intensification of the force with which a sentence is maintained.

The authors formulate a question and they offer the answer too: "could relevance be defined not just as a comparative but as a quantitative concept? Our answer is: yes, it could" (Sperber \& Wilson, 1995, p. 125).

Indeed, following an example given by Sperber \& Wilson, 1995, p. 109), we can see how the relevance of an assumption increases by producing additional information:

(81) (a) If Peter, Paul and Mary came to the party, the party was a success.

(b) Peter came to the party.

(c) Paul came to the party.

(d) Mary came to the party.

(82) The party was a success.

We can notice that additional premises (b), (c), (d) simplify any potential cognitive effort of the receptor in order to understand the enunciation (81). These additional premises are partially included in the condition formulated in (81). Finally, the enunciation (82) underlines the second part of the assumption (81). effects.

The example of the two authors can be processed to illustrate the other two ways to achieve contextual

Therefore, the suppression of information implies the lack of premises (b), (c), (d):

(81) (a) If Peter, Paul and Mary came to the party, the party was a success.

(82) The party was a success.

In this case, the receptor must make a minimal effort in order to understand the enunciation (81) Aided by the enunciation (82), the receptor must assume that the expressed condition has been fulfilled: both Peter, Paul, as well Mary came to the party.

Also, a contextual effect can be obtained by introducing an intensifier.

5 “[Relevance shows that $]$ an assumption is relevant in a context if and only if it has some contextual effect in that context." (Sperber \& Wilson, 1995, p. 122). 
(81) (a) If Peter, Paul and Mary came to the party, the party was a success.

(82) The party was a real success.

The intensifier real simplifies the cognitive effort of the receptor to understand the enunciation (81): that means certainly Peter, Paul and Mary came to the party.

If it "is easy enough to identify a variety of factors that might make it possible to predict which information will have the greatest contextual effects" (Sperber \& Wilson, 1995, p. 131), it stands to reason that politicians-unfortunately, a (great) part of them-exploit this principle not for a relevant communication of information, but for the transmission of information which is already offered, the interpretation included.

The aspects of verbal communication are summarized by Sperber \& Wilson (1995, p. 232) in this way: "The propositional form of an utterance is an interpretation of a mental representation of the speaker which can be entertained as an interpretation [or] a description". We can have an interpretation of "an actual (e.g. attributed) representation" or of "a desirable (e.g. relevant) representation". The description can refer to "an actual state of affairs" or to "a desirable state of affairs".

Particularly in electoral campaigns, politicians almost always resort to interpretative use of representation to the detriment of descriptive use, although the latter corresponds in fact to their mission: to present their own political platforms. Thus, the receptors' task is twofold. First of all, the background of the statement needs to be restored and only after that the information can be processed for the purpose of a personal interpretation. Of course, at this point of the discussion we do not have to take unilaterally the concept of subjectivity. Catherine Kerbrat-Orecchioni (1980, p. 32) makes a pertinent observation regarding the competence of partners in a communication situation. The communicative competence of the partners involves a series of 'images': everyone's image of themselves, everyone's image of the other, and the possible self-image of each other's consciousness. Consequently, in discursive practice, we do not address the real recipient, but the one built by our subjectivity, and the recipient decodes the message according to what he thinks he knows about the emitter. This is the struggle in the political speech of the campaign: politicians try to (de)construct their image in such a way that voters can no longer reach the real image.

\section{Romanian parliamentary elections on 11 December 2016}

In what follows, it will be seen how politicians manage to deliver large contextual effects in a way that reduces the effort of processing the message by the receptor to a particular interpretation. But, first, let us see the general context.

This electoral campaign was characterised by lack of inspiration, there were no debates between important candidates, and it unfolded in an atmosphere marked by some apathy and non-combat that was clearly to the benefit of the $\mathrm{PSD}^{6}$. The main political groups were PSD and $\mathrm{ALDE}^{7}$, together versus $\mathrm{PNL}^{8}$. The candidate of PNL was supported by USR ${ }^{9}$, a new political formation. In opposition to all of them, was $\mathrm{PMP}^{10}$, a party headed by former president of Romania, Traian Băsescu.

Political enemies repeatedly appealed to attacks on the person but did not apply crucial coups like in other campaigns. Perhaps the only coup under the belt that mattered was the public disclosure of the salary received from the EU by the PNL candidate (Dacian Cioloș). Thus, as the political analysts remarked, an emotional campaign theme of the PNL ("undeserved salaries and pensions" for the privileged categories of the PSD system) was cancelled due to a potential boomerang effect.

\footnotetext{
${ }^{6}$ Social Democrat Party.

${ }^{7}$ An eclectic political formation (a faction detached from the PNL plus migrants from other parties).

${ }^{8}$ National Liberal Party.

${ }^{9}$ Union Save Romania.

${ }^{10}$ Popular Movement Party.
} 
PSD had a sober campaign. Liviu Dragnea, the president of the PSD, recommended to his candidates: "We do not make rallies, do not organize shows, do not throw confetti in the air". So, the social-democrats heavily popularized the government program in which they promised an avalanche of salary increases and tax cuts. The liberals hardly started the political struggle and pushed forward the image of the prime minister Dacian Cioloș, still in office. But it seems to have been an uninspired move. PSD won the elections and formed the parliamentary majority with ALDE and then the government.

\subsection{The battle of slogans}

In general, slogans target contextual effects generated by information suppression mode but also use various intensification forms. This is, in essence, the nature of the slogan, which must be concise to be memorable. How inspired it is, this is definitely another problem.

The slogan of the PSD, “Dare to believe in Romania!"a, is a continuation of the one in a previous campaign: "Proud that we are Romanians"b. Actually, the voters are invited to believe in PSD, the party that declares itself to be the only one which can make Romania a country in which Romanian people can live better than they did before. It is an incentive speech, which counts on a nationalist side of the electors, especially from the rural places and with social problems, which means the PSD electoral area.

The president of the party urged the candidates as follows:

You must run for the people you want to represent. What characterizes you all, [...] and the great mass of the PSD is the love for people. [...] This has also helped me to conceive this development program that starts to show its fruits, a program [...] that has been criticized, [...] because for the first time someone in the Government has thought about the nine million of Romanians living in the Romanian villages. [...] I also want to ask you, in fact, to ask you to go with confidence in these elections. Yes, that is, we are everybody's target.

(Liviu Dragnea, the president of the party, at the launch of PSD candidates, 15.04.2016) ${ }^{11}$

We can see the exploitation of the emotional plateau ("What characterizes you all, [...] and the great mass of the PSD is the love for people"), but also the victimization, a commonly used strategy of this leader ("this development program that starts to show its fruits, a program [...] that has been criticized" and "Yes, that is, we are everybody's target.").

Moreover, ever since the launch of the candidates for the local elections, Liviu Dragnea recommended:

It's a team I know, I'm not a guest here! I understand that today's guest in the county is Băsescu: at the pub, where else should he be? Somebody, a colleague, texted me yesterday and said that, given the fact that Basescu came here, we could still have our conference. How can we not hold it? I don't remember any of us having ever been afraid of Băsescu when he was president, me neither.

(Liviu Dragnea) $)^{12}$

From the rhetorical point of view, here we have an indubitable personal attack to the former president of Romania, Traian Băsescu ("at the pub, where else should he be"). We can see a belligerent attitude, which was accompanied by paraverbal elements; the speaker behaves like a bully in the school yard: "I don't remember any of us having ever been afraid of Băsescu when he was president, me neither". It is an unadulterated baculinum argumentum (in Latin, "the argument of the stick" ${ }^{13}$ ). Several types of individual ethos were discussed in the literature (e.g. Charaudeau, 2005, p. 113-114): the ethos of humanity

\footnotetext{
a In Romanian, "Îndrăznește să crezi în România!”

bIn Romanian, "Mîndri că sîntem români!"

${ }^{11}$ psd.ro, visited on 24 July 2017.

12 psd.ro, visited on 24 July 2017.

${ }^{13}$ In an ironic register, this means the use of force instead of any argument.
} 
and justice, the ethos of character and firmness, and the ethos of seriousness and competence. This speaker, in the absence of a better (political) cause, declares his firmness and his fearless nature in relation to another party leader. Despite the intention of minimizing the opponent, the effect may be the opposite, because common sense says: if you repeatedly pay too much attention to someone, other people might think you are afraid of that person.

The slogan of the PNL was "Romania ahead!"c. Here we can detect a pun based on homophony of the Romanian adverb inainte, which does not the only mean "ahead", but also "before", thus recalling the expression before anything else (so, Romania must be on the first place in our mind). If the comma had been used after the noun Romania (which is mandatory after a noun in the vocative case), the significance of inainte would have been reduced to ahead. This significance remains predominant, as the PNL candidate even explains:

I would end by saying that some people said they wanted Romania back. I believe that, more than ever, having our Romania, assuming responsibility for that, it is good to see a Romania ahead.

(Dacian Cioloș, the PNL candidate, at the launch of PNL candidates, 6.11.2016) ${ }^{14}$

It is obvious that the speaker exploits the antonymy between back and abead. At the launch of the PNL candidate for presidential elections (Klaus Iohannis, the president in office), Alina Gorghiu, a PNL spokesman, recycled the phrase "to take back the country", which was used after the failure of the referendum on dismissal of the former president Băsescu. She said: "We will launch today the one who will be the president of Romania for 10 years! We will win, we have no doubt, we want Romania back!" ${ }^{5}$.

The slogan of the USR was "Finally, you have with whom!"d. This is a pun based on an allusion. In almost every campaign for parliamentary or even presidential elections, it was said that, in fact, the voters chose the smaller disaster (of course, the disaster concerns the candidates). Now, we have with whom, the candidate supported by USR (that proposed by PNL) deserves our vote. We must notice the expressive value of the adverb finally too, suggesting the relief of voters that the curse of choosing the lesser evil has vanished.

The slogan of PMP has a strong incentive value: "Fight for Romania!"”. The verb fight, used in the imperative, has an expressive value, which transmits determination, involvement.

As a general observation, except for the USR slogan, the noun Romania is used in all the others. It is obvious that the same assumption can be understood differently without a clear context or argumentation. Hence, the only way to direct different receptors to the same interpretation is to select images conforming to the principle of intersubjectivity, in order to stimulate an adequate reaction. These slogans are based on the following presuppositions: if you live in Romania and have the right to vote, you are Romanian; therefore, you have the obligation to fight for your country, to contribute to its progress or, simply, to be proud to belong to it.

\section{Speeches and strategies}

The Romanian politicians, with rare exceptions, have not yet learned to speak in concrete terms, bypassing the more technical issues and embarrassing subjects for them, perhaps because they have nothing to say to us. Instead, they learned how to exploit the emotional lode, some of them better, others less well or even falling into the ridicule.

\footnotetext{
'In Romanian, "România înainte!"

14 antena3.ro, visited on 27 July 2017.

${ }^{15}$ ziare.com, visited on 27 July 2017

dIn Romanian, "În sfîrșit, ai cu cine!"

eIn Romanian, "Luptă pentru România!"
} 
This happens because, more recently, politicians are making (their) 'politics', not communicating. When they have nothing (important) to say, then dramatization, miming dialogue, vague language come into play. The political man turns into a show man; thus, his need for show reduces a possible real dialogue with voters and substitutes captatio with monstratio (Charaudeau, 2005, p. 48). This kind of social drama often excludes proper argumentation and involves all sorts of front aspects: personal front, setting, appearance or manner (Goffman, 2007, p. 30-31).

A definition based on the writer's synthesis of vague language literature offers Green (2013, p. 16): "VL is a set of linguistic forms people employ to moderate the accuracy, certainty, clarity or specificity of a statement". Dysfluency ("a challenge for interpreters who do not know what the speaker/signer is trying to say"), complexity ("When a speaker delivers a convoluted or complicated procedural description") and ambiguity ("A word or phrase is said to be ambiguous when it can be taken to mean more than one thing.") are the main features of VL (Green, 2013, p. 14). After all, one might say that vagueness is one of the basic attributes of natural language. However, in political discourse, vagueness appears either as a form of manipulation or as an expression of the inability and indolence of the speaker. In both cases it is a disrespect to the voters and to the real task of the politician. Politicians should abide by that "contrat parole" (Charaudeau, 1983), a contract that involves some linguistic modalities: correctness (not only grammatical one), fluency, conciseness and clarity.

Metaphors are also forms of vagueness, often used instead of arguments, which are not allowed in such communication, because:

We will consider a figure as argumentative if, leading to a change of perspective, its use seems normal in relation to the new situation suggested. If, on the contrary, the speech does not involve the listener's adhesion to this argumentative form, that figure will be perceived as an ornament, as a figure of style.

(Perelman \& Olbrechts-Tyteca, 1992, p. 229) ${ }^{16}$

Let us start the series of examples with some benign sample of political propaganda:

On 11 December you can make a choice, for you and for your children. You can choose between an irrevocably pro-European country, a country supporting NATO, a county supporting Justice, and a country which remains under the cold Eastern wind.

(Dragoș Pâslaru, at the PNL regional electoral rally, held in Iași, whose theme was "Moldova rises" $)^{17}$

We observe a miming dialogue ("you can make a choice") and exploitation of the sentiment of duty towards children ("a choice [...] for your children") as another element of persuasion. Anaphoric resumption of the noun country becomes an opportunity to bring new determinants, such as: pro-European, supporting and, of course, the intensifier irrevocably. But we do not find out by what "irrevocable" measures PNL intends to make Romania "a pro-European country", "a country supporting Justice", and so on. The antithesis is also used: in contrast to Romania offered by PNL, there appears a Romania offered by their political opponents, "a country which remains under the cold Eastern wind". Obviously, the metaphor "the cold Eastern wind" refers to influence of Russia.

Another politician brings the argumentum of his own example:

Good evening, Iași! Good evening, Moldova! I am the mayor of Bîrlad City, I come from the Lowlands of Moldova and I bring the salute of Bîrlad people, a salute of unity, force and

\footnotetext{
${ }^{16}$ This is the original of my translation from French: "Nous considérerons une figure comme argumentative si, entraînant un changement de perspective, son emploi paraît normal par rapport à la nouvelle situation suggérée. Si, par contre, le discours n'entraîne pas l'adhésion de l'auditeur à cette forme argumentative, la figure sera perçue comme ornement, comme figure de style".

${ }^{17}$ adevarul.ro, visited on 25 July 2017.
} 
determination. We won the town hall of Bîrlad in June 20, and this happened in a county where PSD has been dominating the political life since the Revolution. We won when no one believed in us anymore. For all that, we succeeded. If in Bîrlad prevailed, dear Liberals, it means we can win in Galați, in Bucharest and everywhere in Romania where the Liberals are united and determined. [...] it would be a pity, dear Liberals, for the $1^{\text {st }}$ of December 2018, not to find us in governance, since this is when we celebrate the centenary of the Great Union. Union which was the work of the Liberals led by the prime minister Ion I. C. Brătianu. Let's go ahead with the Liberals!

(Dumitru Boroș, the mayor of Bîrlad, on the same occasion like above) ${ }^{18}$

Because this victory has happened in a part of country "where PSD has been dominating the political life since the Revolution", the value of the example is even stronger. We can also see an anadiplosis ("[...] Union. / Union which was [...]") and the various forms of syntactic parallelism very often used in this type of propaganda discourse. Moreover, if PSD members, often associated with the former Romanian Communist Party, do not appeal to history, on the contrary, the Liberal speakers often resort to this evocation procedure to highlight the historical origins and values of their party ("Union which was the work of the Liberals led by the prime minister Ion I. C. Brătianu”).

The following example is a case where the merely minimal retracing to the enunciation context is necessary. What I mean are especially the speaker data. Leonardo Badea is a young PSD member in his early twenties who is not well-known either in his professional field or in other domains. However, he is promoted in politics. Let us see him in action:

I have always felt and been a child of the Party. I have been what you wanted me to be: president of the PSD Youth Division for Dîmbovița county. It is also you who have supported me to become the youngest county counsellor, it is the same support that took to the Romanian Parliament [...], the same support made me a vice-president of [...] and I tried as hard as I could not to disappoint you and to honour your trust and hope in me [...]

(Leonardo Badea, member of the PSD Youth Division, at the launch of the Dîmbovița county PSD candidates for the Chamber of Deputies) ${ }^{19}$

The data excerpt here seems a 'Copy and Paste' version of a famous oratorical speech, more exactly, the exordium of Cicero's speech in defence of Roscius from Ameria:

I think you, judges, are wondering why, while so many orators and the best-known people do not stand up, I did it instead, I who cannot compare with them in age, talent or authority... But I was talked into it by people whose friendship, the good they invested in me and their fame are priceless for me; so, I owed them a lot of gratitude for their kindness, it was my duty not to disobey their authority and not to disregard their will.

(Cicero, Pro Roscio Amerino, I; in Mihai, 1998, p. 191)

Cicero was only 23, he came from the middle class, was known to be interested in knowledge and that is about all. Apparently, he was not very handsome, but his Latin was impeccable and melodious. Despite this not very favourable social background, for the young man who addressed an audience used to famous speakers for the first time, Cicero managed to attract their attention and goodwill by his moderate and humble but straightforward tone. He also indirectly counted on his already known merits by famous people appreciated by the audience.

The young PSD member seems to be trying to exploit not the same premises but mostly the discursive pattern. Obviously, the result is rather outdated in shape and performance. Anyway, for the initiated,

\footnotetext{
${ }^{18}$ vremeanoua.ro, visited on 25 July 2017.

${ }^{19}$ tvpartener.ro, visited on 25 July 2016.
} 
this is a very easily recognisable model. Regarding the effect coveted by the young politician, we can only quote Quintilian"20: "Without natural gifts, technical rules are useless" (1974, p. 26).

I will conclude this series of examples with a fragment of a speech that was not delivered in the 2016 election campaign, but which is relevant to the argumentative political manner:

We would like to ask Prime Minister Călin Popescu-Tăriceanu if these are the best ministers the Alliance can offer. If [they] are not, it's serious, if [they] are [the best], it's even worse. I still hope that this is a farce, an exercise of image, a testing of the atmosphere, and that when we are all upset, the true Prime Minister, Mr. Traian Băsescu, will turn up with the real government, as he has promised all of us.

(Victor Ponta, in Joint meeting of the Chamber of Deputies and the Senate, 28.12.2004) ${ }^{21}$

The fragment has two parts: a syllogism ("We would like [...], it's even worse") and the ironic comment facilitated by that syllogism ("I still hope [...] as he has promised to all of us"). The argumentation in the first part is an apagogic one because the speaker tries to validate his own thesis by contradicting the thesis of the interlocutor.

The syllogism is based on an ad hominem argumentum and on a fallacious entimemic reasoning: the author deliberately attempts to offer the appearance of the correct deduction of the thesis from avoided premises, considered as being already understood. So, we have a reasoning with gradual variants that lead to the same unformulated thesis. I will combine the two variants $(1,2)$ in the syllogism shown schematically below:

$$
\begin{aligned}
& \mathrm{P}_{\mathrm{M}}<(1) \text { If } \text { [they] are not [the best ministers of the Alliance] or }(2) \text { If } \text { [they] are [the best] }> \\
& \mathrm{P}_{\mathrm{m} 1}<[\text { then }](1) \text { it's serious or }(2) \text { it's even worse }> \\
& \mathrm{P}_{\mathrm{m} 2}<[\text { because everyone can see that they are not good ministers }]>
\end{aligned}
$$

$\mathrm{T}<$ [Therefore], (1) [the Prime Minister is not able to form the government] or (2) [the Prime Minister has no one with whom to form the government] >

\section{where}

$\mathrm{P}_{\mathrm{M}}$ - a major premise, partially formulated (the speaker imagines a response instead of the person being provoked to answer the question);

$\mathrm{P}_{\mathrm{m} 1}$ - a minor premise, partially formulated (without the connector then);

$\mathrm{P}_{\mathrm{m} 2}$ - an unformulated minor premise (avoided, considered already understood);

$\mathrm{T}$ - an unformulated thesis (avoided, considered already understood).

What follows is clear from this: another unformulated thesis, namely that the Alliance does not deserve to govern, either because it is not able to designate an efficient prime minister to form the government, or, whoever would be Prime Minister, he has no chance to recruit the top ministers.

Instead of a direct thesis, that any Alliance government must be rejected, the speaker uses the procedure of irony (see miming good intentions in the statement "I hope"), invoking a farce scenario, a so-called "exercise of image", conceived by political opponents who will finally designate the "true Prime Minister", and he will propose "the true government", "as he has promised all of us".

Obviously, this is an inconceivable scenario, because no party or alliance politically commits suicide by proposing the weakest of its party members, and after that come up with an unassailable government

\footnotetext{
${ }^{20}$ In his preface to Institutio Oratoria, vol. I.

${ }^{21}$ This is the original: "Am dori să-l întrebăm pe domnul prim-ministru desemnat Călin Popescu-Tăriceanu dacă aceștia sînt miniştrii cei mai buni pe care Alianţa îi poate oferi. Dacă nu, e grav, dacă da, e şi mai grav. Eu mai sper încă că e vorba de o farsă, un exercițiu de imagine, o testare a atmosferei, şi că atunci cînd vom fi toți supărați, va apărea adevăratul prim-ministru, domnul Traian Băsescu, cu adevăratul guvern, aşa cum ne-a promis la toți”. (cdep.ro, visited on 5 Sept. 2017).
} 
and say: we have played a little bit with your expectations, we've tricked you, this is the real government. Would that not be a proof of political immaturity? Yes, that is exactly what it would mean, but is precisely the conviction that must be transmitted to the receptors.

\section{Local elections on 5 of June 2016}

So far, we have seen how politicians strive to replace arguments with more or less effective strategies to persuade voters. In this section I will briefly present only a few utterly ridiculous electoral posters ${ }^{22}$. In these cases, it is almost useless to search any trace of communicative relevance. Even if they do not create their slogans themselves, it is sure that they accept them. These slogans are clear proof that some politicians would say anything just to be voted.

The mayor Nicolae Stan, a candidate of the Liberal Movement, wants to get a new mandate with the slogan "That's good, to help each... me!". The starting point is a standard expression, to help each other. Here we have an uninspired substitution figure (me instead of $o t h e r$ ) which results in insignificant rhyme (in Romanian, "Așa e bine / Să ne ajutăm unii... pe mine”). The subtext can be: Give me your vote. If I help you after that, I'll see later.

The name of a candidate for the Mioveni City Hall becomes a substitute for the name and part of the slogan: "Mioveni, your name is Argentina!". The homophonic allusion is obvious: by choosing this lady, the small town of Mioveni will be comparable to Argentina (the republic [sic!]). Equally uninspired is the name of the party that supports her: Party for Argeș and Muscel, namely a party conceived only for a county and an area.

"Evolution, not change!" is another slogan that generates at least stupefaction. Here we have a failed rhetoric figure because evolution, according to any dictionary, and for every meaning of this word, supposes a change.

\section{Final conclusions}

The fragments of speeches and slogans analysed are a small part of a much richer corpus. The most frequent rhetoric and pragmastylistic strategies in the examples presented in this paper, as in all the others included in the extended corpus, are the following:

- the exploitation of the emotional plateau, in general and in diverse forms;

- imperative enunciations (frequently, the incentive type);

- ad hominem argumentum (in general, by paraphrase and quotation); also, this type of argument is often present in the form of personal attack;

- baculinum argumentum - in Latin, the argument of the stick;

- rhetorical exclamations and rhetorical questions (in an extensive sense, are also forms of vague language especially when the answer is not truly implicit in that rhetorical question or the speaker does not answer it himself);

- various forms of pun, exploiting antonymy, homophony, allusion etc.;

- metaphor, diverse forms of morphological and syntactic parallelisms;

- various forms of vague language (hedges, vague quantifiers, general nouns and verbs, indefinite pronouns etc.); in a broad sense, most of the rhetorical-stylistic figures and procedures belong to vagueness of language, especially when they betray in one way or another the condition of authentic persuasiveness: to have an argumentative function, by supporting the argumentation itself, not by substituting it.

According to relevance theory, in the case of the speeches, the contextual effects are obtained primarily through an addition of information and also through intensification of the force with which a statement

${ }^{22}$ All the posters analysed are found at: ziare.com, visited on 17 August 2017. 
is maintained. In the case of the slogans (used in political rallies or in electoral posters), the contextual effects are obtained primarily through an apparent suppression of information: the slogans are concise but allusive and very incentive. It would seem that the desideratum of relevance is achieved in accordance with this theory: the contextual effects exist, so the interpretive process is diminished.

However, the relevance of political propaganda enunciations (mainly in election campaigns) is seriously affected when "a mental representation" is "entertained as an interpretation of an actual representation" or "a desirable representation" (Sperber \& Wilson, 1995, p. 232), because interpretation is achieved as a result of processes of rhetorical manipulations-some softer, others harder.

First of all, political speeches of this type should be authentically informative, if they were to serve the citizens, which does not exclude expressivity and ingeniousness. Communication of information must be realised as "a description of an actual state of affairs" or "a desirable state of affairs" (Sperber \& Wilson, 1995, p. 232). But since, unfortunately, the political platforms of nowadays parties are not consistent, politicians hide the lack of substance by means of the above-mentioned irrelevant devices which mime relevance.

\section{Bibliography}

Charaudeau, P. (1983). Langage et Discours, Eléments de sémioliguistique (Théorie et pratique) [Language and Speech. Elements of Semioliguistics (Theory and Practice)], Hachette, Paris.

Charaudeau, P. (2005). Le discours politique. Les masques du pouvoir [The political speech. Masks of power], Vuibert, Paris.

Goffman, E. (2007). Viața cotidiană ca spectacol [Everyday life as a show], $2^{\text {nd }}$ edition, comunicare.ro, București.

Green, D.J. (2013). Keeping it Vague: A Study of Vague Language in an American Sign Language Corpus and Implications for Interpreting between American Sign Language and English, Master's Theses, [online].

Ionescu-Ruxăndoiu, L. (2007). Sugestii privind interpretarea pragma-retorică a discursului electoral [Suggestions on pragmarhetorical interpretation of electoral discourse], in Stan, C., Zafiu, R. \& Nicolae, Al. (eds). Studii lingvistice. Omagiu profesoarei Gabriela Pană Dindelegan, la aniversare [Language studies. Homage to Professor Gabriela Pana Dindelegan at anniversary], Editura Universității București, București.

Kerbrat-Orecchioni, C. (1980). L'Énonciation. De la subjectivité dans la langage [The Enonciation. Subjectivity in language], Armand Colin, Paris.

Mihai, Gh. (1998). Retorica tradițională și retorici moderne, ALL, București.

Quintilian (1974). Arta Oratorică [Institutio oratoria], vol. I., transl. by Maria Hetco, Minerva, București.

Perelman, C. \& Olbrechts-Tyteca, L. (1992). Traité de L'Argumentation. La Nouvelle Rhétorique [Treatise of Argumentation. The New Rhetoric], $5^{\text {th }}$ edition, L'Université de Bruxelles, Bruxelles.

Plett, H.F. (1983). Știința textului și analiza de text [Text Science and Text Analysis], Univers, București.

Sperber, D. \& Wilson, D. (1995). Relevance. Communication and Cognition, Blackwell, Oxford / Cambridge, MA. 